Polonia Sacra 18 (2014) nr 4 (37) · s. 81-99

\author{
Barbara Witos ${ }^{1}$
}

Uniwersytet Papieski Jana Pawła II w Krakowie

\title{
Freski o tematyce maryjnej \\ z katakumb św. Pryscylli jako zapis wczesnochrześcijańskiej pobożności
}

Klasycznymi opracowaniami tematyki fresków w rzymskich katakumbach są prace Antonia Bosio ${ }^{2}$, Giovanniego Battisty de Rossi ${ }^{3}$ czy Raffaela Garucciego ${ }^{4}$. Pierwszą publikacją poświęconą całkowicie tematyce malarstwa katakumbowego jest dzieło Giuseppe Wilperta ${ }^{5}$. Spośród studiów polskich badaczy zajmujących się motywami maryjnymi w malarstwie katakumbowym należy wymienić prace Leona Łomińskiego ${ }^{6}$, Bożeny Iwaszkiewicz-Wronikowskiej,

1 Barbara Witos, ur. 1980 w Żywcu, magister licencjat teologii. Doktorantka III roku na Wydziale Teologicznym UPJPII w Krakowie (zakres - patrologia, promotor - o. dr hab. Dariusz Kasprzak prof. UPJPII), katechetka w Zespole Szkół Łączności w Krakowie. Absolwentka studiów podyplomowych z franciszkanizmu na Wydziale Teologicznym UPJPII w Krakowie. Praca magisterska - Tematyka życia w świetle listu św. Pawła do Filipian. Wybrane aspekty egzegetyczno-teologiczne, praca licencjacka - Historyczno-teologiczne znaczenie grot Nowego Testamentu.

2 A. Bosio, Roma sotterranea, Roma 1632.

3 G. B. de Rossi, Roma Sotterranea Cristiana, Roma 1864.

${ }_{4} \quad$ R. Garrucci, Storia dell'arte cristiana nei primi otto secoli della chiesa, t. 6, Prato 1872-1881; R. Garrucci, Dissertazioni archeologiche di vario argomento, t. 2, Roma 1864-1865.

5 G. Wilpert, Le pitture delle catacombe romane, Roma 1903.

$6 \quad$ L. Łomiński, Matka Boża w katakumbach. Studium archeologiczne wydane w XV-to wiekowa rocznicę ogłoszenia dogmatu o boskim macierzyństwie Marji w Efezie (431-1931), Łódź 1931.

7 B. Wronikowska, Picturae sacrae. Motywy ikonograficzne malowideł przedkonstantyńskich w chrześcijańskich katakumbach Rzymu, Lublin 1990; B. Wronikowska, Najstarsza ikonografia ma- 
Jana Stanisława Partyki ${ }^{8}$ i Justyny Sprutty ${ }^{9}$. W przytoczonych opracowaniach nie podejmowano jednak tematyki pierwszych fresków maryjnych jako zapisu wczesnochrześcijańskiej pobożności. Stąd w niniejszym studium, posługując się metodą historyczną i teologiczną, chcę przeanalizować opisany materiał archeologiczny i spróbować odpowiedzieć na pytanie: na ile freski z katakumb mogą stanowić ewentualny zapis pobożności? Na początku pragnę przytoczyć podstawowe dane historyczne dotyczące katakumb i znajdujących się w nich fresków. Następnie dokonam opisu katakumb Pryscylli oraz wybranych fresków maryjnych z tych katakumb, by na koniec określić ich znaczenie religijne.

\section{Katakumby rzymskie i freski o tematyce maryjnej (II-IV wiek)}

Chrześcijanie dużą uwagę przywiązywali do pochówku swych zmarłych. Troską otaczano nie tylko ciało zmarłego, ale również miejsce, w którym zostało ono złożone. Było to podyktowane kilkoma czynnikami: naśladownictwem pogrzebu Jezusa, wiarą w życie wieczne oraz szacunkiem do ciała, które mocą Bożą ma powstać z martwych. Zwyczaj grzebania zmarłych w ziemi na publicznych nekropoliach został częściowo przejęty z tradycji pogańskiej, co wynikało często z braku własności ziemskiej, którą chrześcijanie mogliby wykorzystać na miejsca pochowku ${ }^{10}$. Ciała zmarłych składano na pogańskich nekropoliach naziemnych, położonych z dala od miast, ze względu na prawo rzymskie, które zabraniało grzebania zmarłych w obrębie murów miejskich ${ }^{11}$. Dobrym tego przykładem są groby świętych, któ-

ryjna - Madonna z Dzieciątkiem w rzymskim malarstwie katakumbowym, [w:] Maryja w tajemnicy Chrystusa, red. S. C. Napiórkowski, S. Longosz, Niepokalanów 1997, s. 134-164.

8 J. S. Partyka, Najstarsze wizerunki Matki Bożej z rzymskich katakumb, „Salvatoris Mater” (2000) 1 (5), s. 272-291.

9 J. Sprutta, Najstarsze przedstawienia MatkiBożej, ,Salvatoris Mater”(2009) 2 (42), s. 151-157.

10 Belgijski badacz katakumb Louis Reekmans na podstawie prowadzonych przez siebie badań stwierdził, że chrześcijanie otrzymywali grunty na własność dopiero w III wieku. Por. J. S. Partyka, Najstarsze wizerunki Matki Bożej..., dz. cyt., s. 275.

${ }_{11}$ Jak podaje M. Zajęcki, Cmentarz w mieście feudalnym, czyli o sacrum w obliczu zasady racjonalności, „Gryfiński Kwartalnik Historyczny” (2005) 1 (9), s. 21, w Prawie Dwunastu Tablic znajdujemy klasyczny zapis prawa dotyczący pochówków poza miastem: „hominem mortuum in 
rych ciała spoczęły na pogańskich nekropoliach w Rzymie: św. Piotra przy via Cornelia oraz św. Pawła przy via Ostiense. Po edykcie mediolańskim z 313 roku, na którego mocy chrześcijaństwo stało się w Cesarstwie Rzymskim religią prawnie uznaną (religio licita), zaczęto nad grobami męczenników wznosić bazyliki. Zdarzało się, że ciała męczenników przenoszono do nowo powstałych kościołów ${ }^{12}$. Od 313 roku pojawił się też zwyczaj grzebania wiernych w obrębie murów kościelnych. Ze względu na limit miejsca w samych kościołach zasadniczą przeszkodą było stopniowe wyczerpywanie się miejsc grzebalnych. Stąd od V wieku w kościołach postanowiono chować jedynie duchownych i osoby szczególnie zasłużone. Natomiast wszystkich pozostałych wiernych zaczęto chować na placu przed lub wokół kościoła otoczonego parkanem albo murem ${ }^{13}$. Na Wschodzie prawo dotyczące miejsc pochówku usystematyzował Corpus Iuris Civilis (Digesta 11,8,3) cesarza Justyniana z 534 roku, na mocy którego cmentarze lokowano już w obrębie murów miejskich. Na Zachodzie podobne prawo spotykamy również od VI wieku. Dekrety synodu w Bradze w 563 roku zakazywały jeszcze grzebania w kościołach, dozwoliły natomiast na umieszczanie grobów po zewnętrznej stronie muru kościelnego ${ }^{14}$.

urbe ne sepeliio neve unto”, czyli: „nie będzie zmarły człowiek w mieście pochowany ani skremowany" (Fontes Iuris Romani Antejustiniani, pars prima X, I, a cura di S. Riccobono, Florentiae 1941). Według opinii F. de Visschera, Le droit des tombeaux romains, Milano 1963, s. 60, 147, zasada ta oznaczała przystosowanie porządku prawnego do miejskiego stylu życia, gdyż w najdawniejszym okresie dziejów Rzymu zdarzały się przypadki grzebania zmarłych w domach. W komentarzach Cycerona, O prawach, XXIV, 61, do tego fragmentu Prawa Dwunastu Tablic znajdujemy wzmiankę o zasadzie stosowanej raczej w warunkach wiejskich, iż zmarłego nie można chować w odległości mniejszej niż 60 kroków od cudzego domu; Por. B. Filarska, Archeologia chrześcijańska, Warszawa 1999, s. 9-13; M. Girardi, Katakumby. Podziemne cmentarze, [w:] Encyklopedia chrześcijaństwa. Historia i współczesność 2000 lat nadziei, tłum. S. Bielański i in., red. H. Witczyk, Kielce 2000, s. 330-331.

12 Por. W. Rordorf, Martirio, [w:] Dizionario patristico e di antichità christiane, vol. II., a cura di A. Di Berardino, Casale Monferrato 1983, s. 2133-2135.

13 Por. D. Kasprzak, Starożytne chrześcijaństwo w mieście, „Studia Laurentiana” 3 (2003) 1, s. 23.

14 Ph. Ariès, Człowiek i śmierć, przeł. E. Bąkowska, Warszawa 1989, s. 43, podkreśla, że zakazy grzebania zmarłych w kościołach były powtarzane w postanowieniach kolejnych synodów (np. Moguncja z 813 r.; Tribur z 895 r.; Nantes z 900 r.). W samych kościołach czyniono jednak nadal wyjątki od tej reguły kościelnej dla pochówku świętych, zakonników, kapłanów czy panów feudalnych. Por. Z. Morawski, „Intra muros”. Zarys problematyki cmentarza miejskiego w średniowieczu, 
W II wieku zaczęto w Rzymie upowszechniać egipski zwyczaj grzebania zmarłych, praktykowany również w religii żydowskiej. Polegał on na chowaniu zmarłych w korytarzach wykutych pod powierzchnią ziemi. Powstawało coraz więcej cmentarzy podziemnych, które dopiero od IX wieku były określane jako katakumby ${ }^{15}$. Zdarzało się, że cmentarze te były sponsorowane przez bogatych chrześcijan, aby dzięki ich darowiznom mogli tam zostać pochowani także ubożsi współwyznawcy. W dowód wdzięczności taki kompleks cmentarny określano imieniem własnym darczyńcy, stąd np. katakumby Pryscylli czy Domicylli. Chrześcijanie organizowali między sobą zbiórki pieniężne zarówno na utrzymanie, jak i na pochówek biedniejszych spośród siebie, co poświadczyli Tertulian ${ }^{16}$ i Hipolit ${ }^{17}$.

Podziemne cmentarze powiększano, wydłużając korytarze i tworząc piętra połączone z sobą schodami. W ścianach korytarzy drążono piętrowo podłużne loculi (nisze grobowe), w które wsuwano owinięte w białe płótno ciało zmarłe-

[w:] Czas, przestrzeń, praca w dawnych miastach. Studia ofiarowane Henrykowi Samsonowiczowi w sześćdziesiątą rocznicę urodzin, Warszawa 1991, s. 93-94.

${ }_{15}$ Pierwotnie używano terminu coemeterium z greckiego koimhth,rion, co w rozumieniu chrześcijańskim opierało się na wierze w zmartwychwstanie ciał i oznaczało „miejsce odpoczynku”, „sypialnię”. Natomiast pogańskim odpowiednikiem miejsca przeznaczonego na grzebanie umarłych była nekropolia. Z kolei słowo catacumba oznaczało „otwór”, „wydrążenie”, w języku greckim kata, tu,mboj oznacza „przy uskoku”. Rzymianie określali nim początkowo jedną z miejscowości przy Via Appia, słynąca z dołów, które zasypywano tufem wydobywanym w czasie budowy podziemnych nekropoli, i znajdujący się w pobliżu tej miejscowości cmentarz św. Sebastiana. Z biegiem czasu termin „katakumby” został przyjęty jako powszechnie stosowany na określenie wszystkich rzymskich podziemnych cmentarzy. Por. M. Girardi, Katakumby..., dz. cyt., s. 330; J. S. Partyka, Najstarsze wizerunki Matki Bożej z rzymskich katakumb..., dz. cyt., s. 275.

${ }_{16}$ Tertulian, Apologetyk 39, 6: ,...każdy przynosi umiarkowany datek w oznaczonym dniu miesiąca, albo kiedy chce i o ile może. Nikogo tu nie niewolą, ale każdy swój datek daje dobrowolnie. Są to jak gdyby składki pobożności. Bo z kasy tej nie wydaje się ani grosza na uczty i pijatyki lub obżarstwo bez pożytku, ale na życie i pogrzeb biednych, na utrzymanie chłopców i dziewcząt, którzy rodziców stracili i środki do życia, dla starców, którzy pracować nie mogą i z domu nie wychodzą, dla rozbitków okrętowych, a ci, którzy w kopalniach, na wyspach lub w więzieniach siedzą, o ile religia Boga naszego tego przyczyną, to za swe wyznanie są uprawnieni do zaopatrzenia", tłum. J. Sajdak, Poznań 1947, s. 157-158 (Pisma Ojców Kościoła, 20).

17 Tradycja apostolska 40: „Nie powinno obarczać się ludzi przy pogrzebie na cmentarz, bowiem taki jest los każdego biedaka. Jednakże niech zapłacą temu robotnikowi, który wykopał dół i zwrócą wartość cegły. Tych natomiast, którzy znajdują się na tym miejscu (tj. cmentarzu) i mają (o nie) troskę, winien utrzymywać biskup, aby nikt z tych, którzy przychodzą na to miejsce, nie był obarczony”, tłum. H. Paprocki, „Studia Theologica Varsaviensia” 14 (1976) 1, s. 167. 
go, bez trumny, a następnie zasłaniano je kamiennymi płytami i pokrywano tynkiem, co stanowiło doskonałe podłoże do dekoracji grobowej. Nie wszystkie jednak groby dekorowano czy opisywano, wiele z nich na zawsze pozostało anonimowe. Loculusy były przeznaczone dla biedniejszej warstwy społecznej chrześcijan, ciała męczenników oraz zamożnych chrześcijan składano w sarkofagach, które następnie układano w komnatach podziemnych zwanych cubicula. Innym znanym rodzajem grobu, który można spotkać w cubiculach, są tzw. arcosolia. Arcosolium była to nisza grobowa z łukowatym obramowaniem wykuta pionowo w ścianie, zasłonięta poziomo kamienną lub marmurową płytą zakrywającą ciało zmarłego. Arcosolia wyróżniały się bogactwem zdobień, przede wszystkim freskami. Jeszcze inny rodzaj grobów stanowiły krypty, czyli podziemne kościoły ozdobione freskami, inskrypcjami, mozaikami utworzone za czasów św. Damazego - papieża z grobów męczenników ${ }^{18}$.

Malarstwo katakumbowe stanowi najstarszy przykład rzymskiej sztuki chrześcijańskiej. Nie był to styl oryginalny, ponieważ sztuka chrześcijańska miała swoje korzenie w sztuce pogańskiej ${ }^{19}$. Związek ten widać w malarstwie. Artyści często korzystali z gotowych wzorców pogańskich i udoskonalali je motywami chrześcijańskimi. Sztuka katakumbowa z pierwszego okresu obfituje w rozmaitą symbolikę - przewagę stanowią znaki wyrażające tożsamość pierwszych chrześcijan (np. ryba, chleb, kotwica). Od III wieku symbolikę uzupełniano scenami zaczerpniętymi z życia. Spotkać można również sceny biblijne (cykl z Jonaszem i Jezusem Zmartwychwstałym, ofiara Abrahama, chrzest Jezusa) ${ }^{20}$.

18 Por. B. Filarska, Początki sztuki chrześcijańskiej, Lublin 1986, s. 19-22; początki pierwotnych obszarów przeznaczonych na podziemne cmentarze z końca II wieku wraz z planem cmentarzysk i planami budowy ówczesnych grobów szczegółowo opisują: V. Fiocchi Nicolai, Strutture funerarie ed edifici di culto paleocristiani di Roma dal IV al VI secolo, Città del Vaticano 2001, s. 15-32; F. Pergola, Le catacombe romane. Storia e topografia. Catalogo a cura di Palmira Maria Barbini, Roma (b.r.), s. 133-135; J. S. Partyka, Najstarsze wizerunki Matki Bożej z rzymskich..., dz. cyt., s. 273-277.

19 B. Osińska, zaznacza: „Pierwsi chrześcijanie byli obywatelami rzymskimi przyzwyczajonymi do wyrażania swoich myśli i uczuć w sposób zgodny z wielowiekową tradycją, w której się wychowali. Cała sztuka wczesnego okresu chrześcijaństwa jest próbą pogodzenia tradycyjnego wyrażania z nową, zupełnie różną od antycznej, wiarą. A więc nowe treści religijne ubierano w starą tradycyjną formę. W konsekwencji dawne motywy i tematy nabierały nowego, ukrytego znaczenia", Sztuka i czas, t. 1, Od prehistorii do rokoka, Warszawa 2004, s. 69-70.

${ }_{20}$ Por. B. Filarska, Poczatckisztuki chrześcijańskiej..., dz. cyt., s. 35-48;J. S. Partyka, La résurrection de Lazare dans les monuments funéraires des nécropoles chrétiennes à Rome, peintues, mosaïques et décors 
Na freskach z rzymskich katakumb Maryja była ukazywana albo jako Matka Jezusa, albo jako orantka. Najczęściej spotykany obraz z Maryją w roli głównej to scena przedstawiająca Hołd Magów vel Mędrców ze Wschodu. Fresk o tej tematyce znajdujemy na ścianach kilku katakumb, w tym m.in. Pryscylli, Piotra i Marcelina, Domicylli, Agnieszki, Kaliksta. Różnice, jakie pojawiają się w zestawieniu sceny Hołdu Magów z wymienionych katakumb, to przede wszystkim liczba Magów, która waha się od dwóch do czterech. Na wszystkich tych freskach w centrum ukazany jest Jezus, którego postać autorzy umieścili na kolanach Matki. Zdaniem Bożeny Iwaszkiewicz-Wronikowskiej początków ikonografii maryjnej można się doszukiwać właśnie w scenach pokłonu Magów, a charakterystyczna postać Maryi siedzącej na tronie stała się po 431 roku wzorem dla obrazów maryjnych, np. tego, który znajduje się w Santa Maria Maggiore w Rzymie ${ }^{21}$. Jak odnotowuje Dariusz Kasprzak, w historii kultu odnajdujemy pewne podobieństwa starożytnego wzoru ikonograficznego bogini Izydy z synem na kolanach - do Maryi z Jezusem na kolanach. Jednak w zestawieniu ikonografii Izydy z ikonografią maryjną nie spotykamy istotnych szczegółów: Maryja w odróżnieniu od Izydy nie jest przedstawiana z krzesłem czy jego ikonicznym odpowiednikiem na głowie, Jej głowa nie jest też ozdobiona krowimi rogami (symbol nieba). Brak zatem istotnych atrybutów bogiń z mitologii egipskiej w ikonicznych przedstawieniach Maryi. Co więcej, kult maryjny w chrześcijaństwie i kulty antycznych bogiń były rozbieżne doktrynalnie, niespójne teologicznie, brak też jakichkolwiek ciągłości i przechodzenia jednego kultu w drugi ${ }^{22}$.

Innym powtarzającym się motywem jest Madonna z Dzieciątkiem - spotykamy go m.in. u Pryscylli, św. Walentyna i w Cimiterium Maius (znanym jako katakumby św. Agnieszkiin ${ }^{23}$. Obrazy te różnią się między sobą. Fresk w katakumbach św. Walentyna przedstawia Maryję z Dziecięciem na ko-

des épitaphes:étude archéologique, iconographique et iconologique, Warszawa 1993 (Travaux du Centre d'Archéologie Méditerranéenne de l'Académie Polonaise des Sciences, 33).

21 Por. B. Iwaszkiewicz-Wronikowska, Najstarsza ikonografia maryjna ..., dz. cyt., s. 138-139.

22 Więcej na ten temat: D. Kasprzak, Oryginalność kultu Maryi z Nazaretu na tle kultów Wielkiej Matki (prahistoria, mity, kulty historyczne Bogini-Dziewicy i Bogini-Matki), „Polonia Sacra” XV/XXXIII (2011) 28 (72), s. 123-158.

${ }^{23}$ Od XVIII wieku uznaje się, że fresk kobiecy z Cimiterium Maius przedstawia kobietę, której szczątki wraz ze szczątkami jej dziecka spoczywają w tym miejscu. Jednak w malarstwie katakumbowym stanowił on jeden ze wzorców maryjnych; por. B. Iwaszkiewicz-Wronikowska, 
lanach. Jej ręce spoczywają na ramionach Syna. Nad ich głowami widnieją nimby. W nimb Jezusa został wpisany krzyż. Obok obrazu widnieje napis „SCA DI GENETRIX” (tj. „Święta Boża Rodzicielka”)24.

W katakumbach spotykamy także sceny obrazujące wydarzenia z życia Maryi, stanowiące ilustracje wybranych perykop Nowego Testamentu. Do najbardziej znanych należy obrazowanie sceny zwiastowania z katakumb Pryscylli oraz sceny nawiedzenia z katakumb św. Walentyna. O pierwszym z nich będzie mowa w kolejnym paragrafie. Drugi fresk, mocno zniszczony, ukazuje dwie kobiety wzajemnie się obejmujące, ubrane w długie płaszcze $\mathrm{z}$ zarysowanymi nad ich głowami nimbami ${ }^{25}$.

\section{Opis katakumb Pryscylli oraz wybranych fresków maryjnych}

W pierwszym wieku po Chrystusie teren, na którym powstały później katakumby Pryscylli, stanowił własność bogatego senatorskiego rodu Acyliuszów (gens Acylia), właścicieli ziemi przy via Salaria. Początkowo było to arenarium, które zostało opuszczone z powodu blokady wejścia na skutek osunięcia się ziemi. Katakumby Pryscylli uważane są za jedne z najstarszych katakumb rzymskich. Ich początki sięgają końca II wieku, a chrześcijańskie korzystanie z hypogeum Acyliuszów datuje się od III wieku²6.

Istnieją przypuszczenia, że pochodząca z senatorskiego rodu Acyliuszów Pryscylla (Priscilla clarissima femina), matka senatora Pudensa, który miał

Najstarsza ikonografia maryjna..., dz. cyt., s. 136; J. Sprutta, Najstarsze przedstawienia Matki Bożej..., dz. cyt., s. 154 .

24 D. Mazzoleni, La catacomba di S. Valentino, „Forma Urbis” 2 (1997) 1, s. 24-27.

25 Por. L. Łomiński, Matka Boża w katakumbach..., dz. cyt., s. 33; Orazio Marucchi, biorąc pod uwagę styl wykonania fresku Nawiedzenie z katakumb św. Walentyna, datuje jego powstanie po IV wieku, dodając, że obraz był zapewne odnawiany w czasach papieża Teodora I (pontyfikat: od 642 do 14 maja 649). Powodem tak późnego datowania są przede wszystkim aureole widoczne nad głowami kobiet. Nimby nad głowami postaci świętych do IV wieku się nie pojawiały, natomiast są one widoczne w dziełach z późniejszego okresu (L. Łomiński, Matka Boża w katakumbach..., dz. cyt., s. 32-33).

26 P. Testini, Le catacombe e gli antichi cimiteri cristiani in Roma, Bologna 1966, s. 74, dowodzi, że pod koniec II wieku istniały w katakumbach Pryscylli dwa centra cmentarne: arenarium i Capella graeca. Natomiast hypogeum Ancyliuszów byłoby używane przez chrześcijan dopiero od III wieku. Było ono własnością senatorską aż do IV wieku. 
u siebie na vicus Patricius gościć Piotra Apostoła, przekazała ów teren gminie chrześcijańskiej na własność. Na tym terenie znajdują się jedne z najstarszych grobów, w tym hypogeum Acyliuszów (to tzw. trzeci obszar katakumb). Katakumby te określano jako regina catacumbarum, czyli „królową katakumb” - zostało tam pochowanych bardzo wielu męczenników oraz innych chrześcijan. Łączną liczbę pochówków w katakumbach Pryscylli archeolodzy określają na 40 tysięcy. Oprócz rodziny wspomnianego wcześniej senatora znajduje się w niej także mauzoleum z ciałami rodu Acyliuszów. Na pierwszym poziomie pochowano kilku papieży, w tym m.in. Marcelina, Sylwestra, Celestyna I. W czasie ostatnich lat prześladowań do tej katakumby złożono ciała wielu męczenników, do najbardziej znanych należą święci: Filip, Feliks, Liberiusz. Na drugim piętrze spoczywały ciała m.in. Akwilli i Pryski - patronów kościoła na Awentynie oraz Praksedy i Pudencjany, córek senatora Pudensa. Katakumby Pryscylli są jednymi z pierwszych katakumb odkrytych w wieku XVI ${ }^{27}$. Katakumby Pryscylli są dwupoziomowe, poziom górny jest starszy. Zostały podzielone na trzy obszary ${ }^{28}$.

Pierwszy rejon to Ka pli c a g r e cka. W jednej ze ścian tej kaplicy wykuto trzy nisze, w których znajdują się dwie inskrypcje w języku greckim - stąd nazwa Capella Graeca. Inskrypcje te są dedykacją niejakiego Obryna skierowaną do Palladiusza i jego żony Nestoriany. Z lewej strony kaplicy wzdłuż ściany ciągnie się długa marmurowa ława. Górna część ścian i sklepienie kaplicy zostało ozdobione freskami biblijnymi i ornamentalnymi. Z przodu na łuku dzielącym kaplicę na dwie części du znajduje się fresk przedstawiający Hołd Mędrców oraz najstarszy wizerunek Matki Bożej z Dzieciątkiem (wokół tego fresku skupia się drugi obszar katakumb). Po przeciwnej stronie łuku zostały

${ }^{27}$ Por. L. Łomiński, Matka Boża w katakumbach..., dz. cyt., s. 26; F. Pergola, Le catacombe romane. Storia e topografia..., dz. cyt., s. 135-136; Le catacombe di Priscilla sulla Salaria Nova, www.antika.it/006296_roma-catacombe-di-priscilla.html (31.07.2013).

${ }_{28}$ Więcej na temat samych katakumb Pryscylli zobacz w opracowaniach: F. Tolotti, L'area recinta ove ebbe origine il cimitero di Priscilla, „Rivista di Archeologia Cristiana” 43 (1968), s. 261-314; L. De Bruyne, La „Cappella Greca” di Priscilla, „Rivista di Archeologia Cristiana” 46 (1970), s. 291330; F. Tolotti, Le cimetière de Priscille: syntèse d'une recherche, „Revue d'Histoire Ecclésiastique” 73 (1978), s. 281-314; B. Filarska, Początki sztuki chrześcijańskiej..., dz. cyt., s. 49; V. Fiocchi Nicolai, Paul-Albert Février, la catacomba di Priscilla e le origine delle catacombe romane, [w:] Paul-Albert Février de l'Antiquité au Moyen Âge, ed. M. Fixot, Publications de l'Université de Provence 2004, s. 259-273. 
namalowane dwie sceny: wskrzeszenie Łazarza oraz Noe w arce. W drugiej części kaplicy usytuowanej za łukiem, znajdują się obrazy: po prawej stronie przedstawiający Daniela w jaskini lwów, a po lewej ofiarę Abrahama. Na ścianie przy wejściu znajdują się kolejne dwa freski. Pierwszy ukazuje mężczyznę z uniesioną w górę ręką oraz trzech młodzieńców w ogniu - scena zaczerpnięta z księgi Daniela (Dn 3, 15-24). Drugi fresk przedstawia postać Mojżesza w chwili wyprowadzenia wody ze skały - obraz ilustrujący scenę z księgi Wyjścia (Wj 17, 6). Najbardziej zniszczonym miejscem w tej części katakumb jest sufit, gdzie w pierwszej jego części zachowała się scena uzdrowienia paralityka przez Jezusa. Natomiast w drugiej części znajdujemy trudne do zidentyfikowania postaci wśród winnej latorośli oraz przedstawienia z życia Zuzanny (Dn 13). W kaplicy greckiej oprócz scen biblijnych spotykamy też sceny ornamentalne: umierającego na stole feniksa, a także głowę ludzką przystrojoną w kłosy zbóż. Nad środkową niszą znajduje się obraz przedstawiający ucztę eucharystyczną ${ }^{29}$. Określenie czasu powstania wymienionych malowideł jest problematyczne. Według hipotez Francesco Tolottiego, podzielanych też przez Bożenę Wronikowską, można przyjąć, że Capella Graeca powstała dopiero w III wieku ${ }^{30}$.

Na nieco późniejszy okres datowana jest kolejna część katakumb Pryscylli, tzw. Cubiculum Velatio. Według Tolottiego miejsce to było wykorzystywane na pochówki od pierwszej połowy III wieku do wieku IV włącznie. Świadczą o tym znaczki znajdujące się na odnalezionych w tym miejscu cegłach. Tutaj, podobnie jak w kaplicy greckiej, duży problem stanowi umiejscowienie fresków w konkretnym czasie. Nie jest wykluczone, że niektóre obrazy w Capella Graeca powstały równocześnie z obrazami z Cubiculum Velatio. Nazwa tej części katakumb pochodzi od fresku znajdującego się w głębi pomieszczenia usytuowanego na jego środkowej ścianie. Fresk ten obejmuje całą szerokość ściany i obrazuje trzy sceny z życia jakiejś kobiety. Pierwsza to scena nauczania, pierwotnie rozumiana jako obłóczyny (stąd nazwa Cubiculum Velatio), scena centralna przedstawia kobietę $\mathrm{z}$ uniesionymi w górę rękami, a scena trzecia - kobietę trzymającą w objęciach dziecko. Na lewej ścianie cubicu-

${ }_{29}$ Por. B. Wronikowska, Picturae sacrae..., dz. cyt., s. 67-68; F. Mancinelli, Katakumby rzymskie, Firenze 1987, s. 28-29.

30 Por. B. Wronikowska, Picturae sacrae..., dz. cyt., s. 66. 
lum przedstawiono ofiarę Abrahama, po prawej - młodzieńców w piecu ognistym. Sklepienie pokrywa cykl fresków obrazujących wydarzenia z życia Jonasza z Chrystusem jako Dobrym Pasterzem w centrum sklepienia. Ścianę wejściową ozdabiają motywy zwierzęce oraz Jonasz wyskakujący z ryby ${ }^{31}$.

Chcę zwrócić uwagę na trzy freski, które znajdują się w najstarszej części katakumb Pryscylli: fresk Maryja z Dzieciątkiem, fresk Zwiastowanie Maryi oraz fresk nazwany Obłóczynami. Duży problem stanowi datacja omawianych fresków. Większość współczesnych badaczy odrzuca teorie wypracowane przez pierwszych badaczy katakumb, że niektóre z fresków powstawały w czasach apostolskich. Uważa się dziś, że najstarsze freski maryjne pochodzą dopiero z końca II wieku². Do IV wieku Maryja była przedstawiana przede wszystkim w towarzystwie Syna (np. fresk przedstawiający Madonnę z Dzieciątkiem w towarzystwie Balaama). Sztuka wczesnochrześcijańska łączyła postać Maryi z tajemnicą wcielenia Jezusa. Obrazowano Maryję, by podkreślić ludzką naturę Syna Bożego ${ }^{33}$. Natomiast od IV wieku pojawiają się w ikonografii katakumbowej związanej z wcieleniem kolejne osoby: Magowie vel Mędrcy, pastuszkowie ${ }^{34}$.

\section{Znaczenie religijne opisywanych fresków}

Fresk ukazujący Maryję z Dzieciątkiem, umieszczony na suficie podziemnego korytarza w katakumbach Pryscylli, uznawany jest za najstarszy wizerunek Maryi z katakumb rzymskich. Współcześni archeolodzy zajmujący się katakumbami rzymskimi, jak Umberto Maria Fasola, Pasquale Testini, Francesco Tolotti określili powstanie fresku Maryi z Dzieciątkiem z katakumb Pryscylli na lata 190-21035. Na fresku widzimy Maryję z przytulonym

\footnotetext{
${ }_{31}$ Por. B. Wronikowska, Picturae sacrae..., dz. cyt., s. 66-67; F. Mancinelli, Katakumby rzymskie..., dz. cyt., s. 29.

32 Por. B. Wronikowska, Picturae sacrae..., dz. cyt., s. 12-13.

${ }_{33}$ Por. T. Dobrzeniecki, Hagia Maria - Theothokos w sztuce wczesnochrześcijańskiej, [w:] Maryja w tajemnicy Chrystusa, dz. cyt., s. 154-155.

${ }_{34}$ Por. B. Iwaszkiewicz-Wronikowska, Tajemnica Wcielenia w najstarszej ikonografii chrześcijańskiej, „Vox Patrum” (2000) 38-39, s. 400.

35 P. Testini, Les catacombes chretiennes à Rome, Rome 1964, 82-87; F. Tolotti, Le cimetière de Priscille..., dz. cyt., s. 281-314; S. Maggio, Come arricchire la catechesi mariana degli adulti leggendo le
} 
do piersi Jezusem. Scena prawdopodobnie przedstawia moment po zakończeniu karmienia Jezusa. Wskazuje na to pozycja, w jakiej przedstawiony został Jezus: z głową lekko odchyloną od piersi matki, wpatrujący się jakby ze zdziwieniem w postać mężczyzny stojącego obok i wskazującego prawą ręką ośmioramienną gwiazdę, która znajduje się nad głową Maryi. Głowę Maryi okrywa przezroczysty szal opadający na ramiona, co było typowym nakryciem głowy zamężnych kobiet. Maryja ubrana jest w płaszcz i prawdopodobnie w tunikę. Lewa ręka Maryi, którą podtrzymuje Jezusa, do okolic łokcia jest bez żadnego okrycia, szeroki rękaw tuniki w czasie unoszenia Dzieciątka mógł się zsunąć i obnażyć rękę Matki. Dziecię Jezus ubrane jest w tunikę ozdobioną od dołu. W historii interpretacji tego fresku problematyczna jest identyfikacja mężczyzny wskazującego gwiazdę. Być może jest to prorok przepowiadający przyjście Mesjasza. Postać ta przyodziana została w szaty charakterystyczne dla ówczesnego filozofa, dodatkowo trzyma w ręce papierowy zwój ${ }^{36}$.

Według Giuseppe Wilperta postać ta przedstawia proroka Izajasza w momencie wypowiadania przez niego słów: „Oto panna pocznie i porodzi syna i nazwie Go imieniem Emmanuel" (Iz 7, 14). Współcześni badacze uważają z kolei, że jest to prorokujący poganin Balaam: „Widzę go, lecz jeszcze nie teraz, dostrzegam go, ale nie z bliska: wschodzi Gwiazda z Jakuba, a z Izraela podnosi się berło"(Lb 24, 17). Gwiazda rozświetlona nad głową Maryi według Wilperta miałaby się odnosić do słów proroka Izajasza mówiącego o światłości rozjaśniającej ciemność, która przyszła na świat w osobie Jezusa: „Naród kroczący w ciemnościach ujrzał światłość wielką, nad mieszkańcami kraju mroków światło zabłysło" (Iz 9, 1). Niestety, fresk ten nie zachował się w całości, jego dolna część uległa całkowitemu zniszczeniu ${ }^{37}$. Podobny obraz miał się kiedyś znajdować w katakumbach Domicylli, dziś pozostały po nim

testimonianze mariane dei primi due secoli, [w:] La Madonna nella vita pastorale, a cura di D. Bertetto, Roma 1982, s. 143; J. S. Partyka, Najstarsze wizerunki Matki Bożej z rzymskich katakumb..., dz. cyt., s. 282-283.

${ }^{36}$ F. Bisconti, La Madonna di Priscilla: Interventi di restauro ed ipotesi sulla dinamica decorativa, „Rivista di Archeologia Cristiana” 72 (1996) 1/2, s. 7-34.

37 Por. B. Iwaszkiewicz-Wronikowska, Najstarsza ikonografia maryjna..., dz. cyt., s. 134-135; J. S. Partyka, Najstarsze wizerunki Matki Bożej z rzymskich katakumb..., dz. cyt., s. 283; G. Wilpert, Le pitture delle catacombe Romane, dz. cyt., s. 172-174; J. Sprutta, Najstarsze przedstawienia Matki Bożej..., dz. cyt., s. 151, 154-155. 
jedynie nikłe ślady. Jak podaje Wilpert, różni się on od fresku z katakumb Pryscylli tym, że Dziecię nie jest przyodziane w żadną szatę, a postać mężczyzny stojąca po prawej, a nie po lewej (jak u Pryscylli) stronie nie jest ubrana w szaty filozofa, lecz w szaty osoby świętej, charakterystyczne dla sztuki katakumbowej. Powstanie fresku maryjnego z katakumb Domicylii jest datowane również na koniec III wieku, lecz określane jako późniejsze w stosunku do fresku Maryja z Dzieciątkiem z katakumb Pryscylii ${ }^{38}$.

Drugim freskiem maryjnym jest obraz przedstawiający scenę Zwiastowania Najświętszej Maryi Pannie. Jest on datowany na początek IV wieku, ze względu na zgeometryzowany podział części ściany, na których został umieszczo$n^{39}$. Antonio Bosio, analizując to przedstawienie, nie daje jednoznacznej interpretacji. Badacz ten uznał, że tak na prawdę nie wiadomo, kogo ten obraz przedstawia, dlatego nie chciał obstawać przy tezie, że jest na nim ukazana postać Maryi. Podobne wątpliwości miał również Giovanni Gaetano Bottari ${ }^{40}$. Natomiast Giuseppe Wilpert po zestawieniu owego fresku z innymi obrazami w pozostałych katakumbach uznał, że przedstawia on postać Maryi podczas zwiastowania ${ }^{41}$.

Fresk ten, podobnie jak wcześniejszy, należy do najstarszych malowideł maryjnych. Artysta, inspirując się ewangelicznym przekazem Łukasza,

38 Por. L. Łomiński, Matka Boża w katakumbach..., dz. cyt., s. 26-29; B. Filarska, Początki sztuki chrześcijańskiej..., dz. cyt., s. 49-52; A. Läpple, Maryja w wierze i życiu Kościoła, przeł. K. Wiśniewska, Warszawa 1991, s. 72.

39 Por. J. S. Partyka, Najstarsze wizerunki Matki Bożej z rzymskich katakumb..., dz. cyt., s. 283.

40 L. Łomiński, Matka Boża w katakumbach..., dz. cyt., s. 30, przytacza opinię G. G. Bottariego, według którego fresk ukazuje, że „niewiasta odziana jest w tunikę przepasaną w biodrach i w zarzucony na wierzch paliusz, okrywający jej głowę. Przed niewiastą stoi mężczyzna, który jakby zbliżał się do niej; ubrany również w tunikę, z krótką narzutką na wierzchu; spod niej wysunięta jest prawa ręka, lewą zaś podtrzymuje koniec swego płaszcza. Co przedstawia ten obraz, bardzo trudno jest orzec; być może, że jest to Zwiastowanie Najśw. Panny”.

${ }^{41}$ L. Łomiński, Matka Boża w katakumbach..., dz. cyt., s. 30: „Scena ta zasługuje na specjalną uwagę, ponieważ zjawia się zupełnie izolowana od innych malatur i nie ma nic wspólnego z jakimś szeregiem, czyli cyklem obrazów chrystologicznych, jak to widzimy w innych malowanych kryptach podziemnych. Fresk ten jest jedynym upiększeniem całego sufitu. Widzimy tu przede wszystkim postać niewieścią, która z głową odkrytą siedzi na niewieścim krześle (katedrze); ubrana jest w długą tunikę. Osoba ta jest upozowaną tak, jakby przemawiała lub wydawała jakieś zlecenie. W obrazie tym nie trudno jest odróżnić Maryję Najśw. Siedzącą na tronie i stojącego obok Niej anioła Gabriela, zwiastującego Najśw. Maryi Pannie, że Ona została wybraną przez Boga na Matką Słowa Wcielonego". 
uchwycił dwa momenty: przybycie archanioła oraz lęk Maryi. Postać archanioła (bez skrzydeł - ten atrybut aniołów pojawił się w ikonografii dopiero w V wieku) obrazuje tutaj kogoś, kto ma coś ważnego do powiedzenia. Anioł został ukazany w pozie pochylonej lekko do przodu, z wyciągniętą przed siebie (w stronę Maryi) ręką. Postać Maryi siedząca na wysokim krześle przypominającym tron królewski wyraźnie odchyla się w tył, jakby chciała zachować bezpieczną odległość od osoby stojącej naprzeciwko. Gest ten obrazuje strach, przerażenie tym, co usłyszała. Fresk ten, obecnie mocno zniszczony, znajduje się na suficie cubiculum w najstarszej części katakumby ${ }^{42}$.

Trzeci fresk, tzw. Obłóczyny z cubiculum Velatio w katakumbach Pryscylii, według najnowszych interpretacji przedstawia nie Maryję Pannę, ale trzy sceny z życia kobiety, której szczątki być może spoczywały w tamtym miejscu. Powstanie malowidła datuje się dziś na ostatnie piętnastolecie III wieku. Wizualnie obraz dzieli się na dwie części. Pośrodku stoi zamożna (świadczy o tym jej strój - dalmatyka w kolorze purpurowym, białe obuwie i okrywający głowę szal, zakończony ozdobami) kobieta, która ma rozłożone i uniesione w górę ręce. Po lewej stronie ukazany jest starzec siedzący na podwyższeniu. Prawą, wyraźnie wyciągniętą przed siebie ręką wskazuje coś osobie, do której jest odwrócony. Za kobietą widać postać młodego mężczyzny w ciemnozielonej tunice, który trzyma przed sobą kawałek płótna obszytego purpurą, a po jej prawej stronie autor namalował kobietę w karmiącą dziecko ${ }^{43}$.

Do XX wieku sądzono, że fresk Obłóczyny z cubiculum Velatio jest wizerunkiem Maryi z Jezusem. Odkrywca fresku Antonio Bosio, widząc w trzeciej scenie kobietę z dzieckiem, uznał, że jest to wizerunek Maryi Panny.Jego interpretację przejął Giuseppe Wilpert, który poszedł nieco dalej, uznając w owej kobiecie Maryję jako wzór dla kobiet składających ślub czystości. Wskazujący na Maryję gest biskupa miał uświadomić dziewczynie ślubującej czystość, że w swym nowym życiu ma obowiązek naśladować Maryję. Według interpretacji Antonio Bosiego zamożną kobietą jest dziewica, która za chwilę ma złożyć ślub czystości. W czasie kazania biskup wskazuje ręką na postać Maryi z Dzieciątkiem przytulonym do piersi, którą autor fresku

42 Por. L. Łomiński, Matka Boża w katakumbach..., dz. cyt., s. 29-31; J. S. Partyka, Najstarsze wizerunki Matki Bożej..., dz. cyt., s. 282-283.

${ }_{43}$ Por. J. S. Partyka, Najstarsze wizerunki Matki Bożej..., dz. cyt., s. 286-287. 
umieścił po prawej stronie. Z biegiem czasu fresk z cubiculum Velatio zaczęto interpretować inaczej niż maryjnie. Wraz z postępem w badaniach nad historią sztuki wczesnochrześcijańskiej uznano, że nie każdy obraz przedstawiający kobietę i dziecko należy interpretować jako wizerunek Matki Bożej. Wywnioskowano, że przedstawia on trzy wydarzenia z życia bliżej nieokreślonej kobiety. Orantka to zmarła kobieta, zapewne pochowana w tamtym miejscu, po jej lewej stronie zaślubiny, a po prawej owoc małżeństwa - macierzyństwo. Kobieta z dzieckiem nie jest wizerunkiem Maryi, postać ta zupełnie do Maryi nie pasuje, ubrana jest bardzo skromnie, nie przypomina Matki Bożej z innych wizerunków w tychże katakumbach ${ }^{44}$.

Wizerunki maryjne z tamtego okresu spotykamy najczęściej w miejscach mających bezpośredni związek z miejscami wczesnochrześcijańskiego pochówku, czyli na płytach pokrywających locula, arcosolia, cubicula, ściany korytarzy katakumb, a także w kaplicach. Ta lokalizacja wiązała się z wymiarem eschatologicznym, wyrażała wiarę w życie wieczne, szczęśliwość zmarłych, a także sugerowała intencje, z jakimi chrześcijanie przychodzili do katakumb. Freski te były malowane zarówno na grobach męczenników, jak i innych chrześcijan.

Najstarszy fresk maryjny z katakumb Pryscylii, znany jako Maryja z Dzieciątkiem, podkreśla znaczenie proroctw zapowiadających przyjście Mesjasza, wypełnionych w osobie Jezusa z Nazaretu i odzwierciedla wiarę w człowieczeństwo Jezusa. Poganin Baalam wskazuje na gwiazdę nad głową Maryi, która według jego proroctwa wygłoszonego przeciwko królowi Moabitów była zapowiedzią Mesjasza: „Wzejdzie gwiazda z Jakuba i powstanie berło z Izraela" (Lb 24, 17). Balaam obwieszcza tym samym nadejście potężnego króla, który szeroko rozwinie swoje panowanie. W tradycji wczesnochrześcijańskiej interpretacji Biblii słowa Balaama były odczytywane jako zapowiedź narodzin Mesjasza ${ }^{45}$. Oprócz akcentowania człowieczeństwa Jezusa autor fresku chciał prawdopodobnie uwypuklić jeszcze kolejne dwa

${ }^{44}$ Por. L. Łomiński, Matka Boża w katakumbach..., dz. cyt., s. 47-50; B. Iwaszkiewicz-Wronikowska, Najstarsza ikonografia maryjna..., dz. cyt., s. 135-136; J. S. Partyka, Najstarsze wizerunki Matki Bożej..., dz. cyt., s. 286-287; J. Sprutta, Najstarsze przedstawienia Matki Bożej..., dz. cyt., s. 153-154.

${ }_{45}$ T. Dobrzeniecki, Hagia Maria - Theothokos w sztuce wczesnochrześcijańskiej..., dz. cyt., s. 155. Por. Ap 22, 16. 
elementy ówczesnej religijności: wyznanie wiary w Jezusa jako Zbawiciela narodzonego z Dziewicy Maryi oraz błaganie Maryi o Jej wstawiennictwo u Boga za zmarłymi ${ }^{46}$.

Religijność chrześcijan pierwszych wieków znajdowała też odzwierciedlenie w przedstawianiu na ścianach katakumb całych scen biblijnych, w tym także scen maryjnych, np. zwiastowania Maryi. Scena zwiastowania Maryi dla pobożności ówczesnych chrześcijan oznaczała nowy początek w historii zbawienia, gdzie Bóg daje ludziom kolejną szansę na odkupienie win i życie wieczne z Nim w niebie. Pierwsi autorzy fresków skupiali się raczej na odwzorowaniu opisu tego wydarzenia zapisanego u Łk 1, 26-38, podkreślając moment zapowiedzi mesjańskich ${ }^{47}$.

Trzeci fresk, tzw. Obłóczyny z cubiculum Velatio, jest dziś interpretowany jako niemaryjny, choć był on wcześniej uznawany z fresk maryjny (Antonio Bosio, Giuseppe Wilpert). Dziś natomiast powszechnie widzi się w nim trzy sceny z życia nieznanej chrześcijanki (Umberto Maria Fasola, Pasquale Testini, Francesco Tolotti, Leon Łomiński; Bożena Iwaszkiewicz-Wronikowska; Jan Stanisław Partyka) ${ }^{48}$.

\section{Podsumowanie}

Omawiane w artykule freski z katakumb Pryscylii powstawały w okresie od końca II do IV wieku. Do XX wieku wszystkie trzy były uznawane za maryjne, w XX wieku krytyka odrzuciła jako niemaryjny trzeci z nich (fresk z cubiculum Velatio przedstawia trzy wydarzenia z życia bliżej nieznanej kobiety). W obrazowości dwóch pierwszych fresków (Maryja z Dzieciątkiem i Zwiastowanie Maryi) możemy się dopatrzeć śladów pobożności maryj-

46 Por. S. Maggio, Come arricchire la catechesi mariana degli adulti leggendo le testimonianze mariane dei primi due secoli, [w:] La Madonna nella vita pastorale, Roma 1982, s. 143; J. S. Partyka, Najstarsze wizerunki Matki Bożej..., dz. cyt., s. 288.

47 Por. M. G. Muzi, La prima iconografia mariana (III-IV secolo), [w:] www.culturamariana. com/pubblicazioni/fine16/pdf/Fine16-Muzi-209-244.pdf, s. 4-5 (01.09.2013).

${ }_{48}$ Por. B. Iwaszkiewicz-Wronikowska, Najstarsza ikonografia maryjna..., dz. cyt., s. 135-136; J. S. Partyka, Najstarsze wizerunki Matki Bożej..., dz. cyt., s. 286-287; L. Łomiński, Matka Boża w katakumbach..., dz. cyt., s. 47-50; J. Sprutta, Najstarsze przedstawienia Matki Bożej..., dz. cyt., s. 153-154. 
nej, w okresie od przełomu II i III do IV wieku. Możemy stwierdzić, że kult Maryi był zależny od kultu Jezusa, nie istniał natomiast jako samodzielny kult maryjny. Od przełomu II i III do IV wieku chrześcijanie szczególnie akcentowali znaczenie Maryi jako Matki zapowiadanego przez proroków Mesjasza oraz jako Matki Zbawiciela. We freskach maryjnych z katakumb Pryscylii można się też domyślić motywu prośby o wstawiennictwo u Boga przez Maryję. Opisywane freski maryjne nie umieszczają postaci Maryi w centrum obrazu, co teologicznie potwierdza jej służebną rolę w historii Bożego planu zbawienia. 


\section{Summary}

Freski o tematyce maryjnej z katakumb św. Pryscylli jako zapis wczesnochrześcijańskiej pobożności

Malarstwo katakumbowe stanowi najstarszy przekład rzymskiej sztuki chrześcijańskiej. $\mathrm{Na}$ freskach z rzymskich katakumb Maryja była ukazywana albo jako Matka Jezusa, albo jako orantka. Najczęściej spotykany obraz z Maryją w roli głównej to scena przedstawiająca Hołd Magów vel Mędrców ze Wschodu. Fresk o tej tematyce znajdujemy na ścianach kilku katakumb, w tym m.in.: Pryscylli, Piotra i Marcelina, Domicylli, Agnieszki, Kaliksta. Innym powtarzającym się motywem jest Madonna z Dzieciątkiem - spotykamy go m.in. u Pryscylli, św. Walentyna i w Cimiterium Maius (znanym jako katakumby św. Agnieszki). Umieszczony na suficie podziemnego korytarza w katakumbach Pryscylli fresk ukazujący Maryję z Dzieciątkiem uznawany jest za najstarszy wizerunek Maryi z katakumb rzymskich. W katakumbach spotykamy także sceny obrazujące wydarzenia z życia Maryi, stanowiące ilustracje wybranych perykop Nowego Testamentu. Do najbardziej znanych należy obrazowanie sceny zwiastowania z katakumb Pryscylli oraz sceny nawiedzenia z katakumb św. Walentyna. Dzisiaj uważa się, że najstarsze freski maryjne pochodzą dopiero z końca II wieku. Do IV wieku Maryja była przedstawiana zawsze w towarzystwie Syna. Sztuka wczesnochrześcijańska łączyła postać Maryi z tajemnicą wcielenia Jezusa. Obrazowano Maryję, by podkreślić ludzką naturę Syna Bożego. Kult Maryi był zależny od kultu Jezusa, nie istniał jako samodzielny.

Słowa kluczowe: katakumby rzymskie, sztuka wczesnochrześcijańska, malarstwo, freski maryjne, podziemne cmentarze, pobożność maryjna

The frescoes devoted to the Virgin Mary of the catacombs of St. Priscilla as a record of early Christians piety

The frescoes of the catacombs of Priscilla, discussed in the article, were formed between the end of the second century to the fourth century. Up to the twentieth century all three were considered as devoted to St. Mary, but then criticism rejected the third of them (the fresco in the cubicle known as the The Velatio, representing three events from the life of an unknown woman). The two other paintings (Mary with the Infant Jesus and The Annunciation) may show the Christians' devotion to St. Mary in the period from the turn of the second and third centuries to the fourth century. It can be stated that the cult of Our Lady existed always in consideration of Her relation to Jesus. It never existed as a separate and exclusive worship of Mary herself. Since the turn of the second and third century to the fourth century, Christians particularly stressed the importance of Mary as the Mother of the Messiah announced by the prophets and as the Mother of the Savior. Frescoes devoted to the Virgin Mary of the catacombs of St. Priscilla depict 


\section{Barbara Witos}

also the theme of dead Christians' prayers who are asking Mary as the Mother of the Messiah for intercession for them with God. The paintings do not give Mary a central place on the images what is a theological confirmation of Her subordinate role in the history of God's plan of salvation.

Keywords: catacombs, frescoes of the Mary, painting, piety, early Christian art, underground cemeteries

\section{Bibliografia}

Ariès Ph., Człowiek i śmierć, przeł. E. Bąkowska, Warszawa 1989.

Bisconti F., La Madonna di Priscilla: Interventi di restauro ed ipotesi sulla dinamica decorativa, „Rivista di Archeologia Cristiana” 72 (1996) 1/2, s. 7-24.

Bosio, Roma sotterranea, Roma 1632.

De Bruyne L., La „Cappella Greca” di Priscilla, „Rivista di Archeologia Cristiana” 46 (1970), s. 291-330.

Filarska B., Archeologia chrześcijańska, Warszawa 1999.

Filarska B., Początki sztuki chrześcijańskiej, Lublin 1986.

Fiocchi Nicolai V., Strutture funerarie ed edifici di culto paleocristiani di Roma dal IV al VI secolo, Città del Vaticano 2001.

Garrucci R., Dissertazioni archeologiche di vario argomento, t. 2, Roma 1864-1865.

Garrucci R., Storia dell'arte cristiana nei primi otto secoli della chiesa, t. 6, Prato 1872-1881.

Girardi M., Katakumby. Podziemne cmentarze, [w:] Encyklopedia chrześcijaństwa. Historia i współczesność - 2000 lat nadziei, tłum. S. Bielański, red. H. Witczyk, Kielce 2000, s. 330-331.

Iwaszkiewicz-Wronikowska B., Tajemnica Wcielenia w najstarszej ikonografii chrześcijańskiej, „Vox Patrum” 38-39 (2000), s. 393-400.

Kasprzak D., Oryginalność kultu Maryi z Nazaretu na tle kultów Wielkiej Matki (prahistoria, mity, kulty historyczne Bogini-Dziewicy i Bogini-Matki), „Polonia Sacra” (2011) 28 (72), s. 123-158.

Kasprzak D., Starożytne chrześcijaństwo w mieście, „Studia Laurentiana” 3 (2003) 1, s. 5-27.

Lapple A., Maryja w wierze i życiu Kościoła, Warszawa 1991.

Łomiński L., Matka Boża w katakumbach. Studium archeologiczne wydane w XV-to wiekową rocznice ogłoszenia dogmatu o boskim macierzyństwie Marji w Efezie (431-1931), Łódź 1931.

Maggio S., Come arricchire la catechesi mariana degli adulti leggendo le testimonianze mariane dei primi due secoli, [w:] La Madonna nella vita pastorale, Roma 1982, s. 79-102.

Mazzoleni D., La catacomba di S. Valentino, „Forma Urbis” 2/1 (1997), s. 24-27.

Morawski Z., „Intra muros”. Zarys problematyki cmentarza miejskiego w średniowieczu, [w:] Czas, przestrzeń, praca w dawnych miastach, red. nauk. A. Wyrobisz, M. Tymowski, Warszawa 1991, s. 93-99.

Muzi M. G., La prima iconografia mariana (III-IV secolo), s. 4-5, www.culturamariana. com/pubblicazioni/fine16/pdf/Fine16-Muzi-209-244.pdf (01.09.2013).

Osińska B., Sztuka i czas, t. 1, Od prehistorii do rokoka, Warszawa 2004.

Partyka S., La résurrection de Lazare dans les monuments funéraires des nécropoles chrétiennes à Rome, peintues, mosaïques et décors des épitaphes: étude archéologique, iconographique et icono- 
logique, Warszawa 1993 (Travaux du Centre d'Archéologie Méditerranéenne de l'Académie Polonaise des Sciences, 33).

Partyka J. S., Najstarsze wizerunki Matki Bożej z rzymskich katakumb, „,Salvatoris Mater” (2000) 1 (5), s. 272-291.

Pergola F., Le catacombe di Priscilla sulla Salaria Nova, www.antika.it/006296_roma-catacombe-di-priscilla.html (31.07.2013).

Pergola F., Le catacombe romane. Storia e topografia. Catalogo a cura di Palmira Maria Barbini, Roma [b.r.w.].

Rordorf W., Martirio, [w:] Dizionario patristico e di antichità christiane, vol. II, a cura di A. Di Berardino, Casale Monferrato 1983, s. 2133-2135.

Rossi G. B., Roma Sotterranea Cristiana, Roma 1864.

Sprutta J., Najstarsze przedstawienia Matki Bożej, „Salvatoris Mater” (2009) 2 (42), s. $151-157$.

Tertulian, Apologetyk, tłum. J. Sajdak, Poznań 1947 (Pisma Ojców Kościoła, 20).

Testini P., Le catacombe e gli antichi cimiteri cristiani in Roma, Bologna 1966.

Testini P., Les catacombes chretiennes à Rome, Rome 1964.

Tolotti F., L'area recinta ove ebbe origine il cimitero di Priscilla, „Rivista di Archeologia Cristiana" 43 (1968), s. 261-314.

Tolotti F., Le cimetière de Priscille: syntèse d'une recherche, „Revue d'Histoire Ecclésiastique” 73 (1978), s. 281-314.

Tradycja apostolska, tłum. H. Paprocki, „Studia Theologica Varsaviensia” 14 (1976) 1, s. $145-169$.

Wilpert G., Le pitture delle catacombe romane, Roma 1903.

Wronikowska B., Najstarsza ikonografia maryjna - Madonna z Dzieciątkiem w rzymskim malarstwie katakumbowym, [w:] Maryja w tajemnicy Chrystusa, red. S. C. Napiórkowski, S. Longosz, Niepokalanów 1997, s. 134-164.

Wronikowska B., Picturae sacrae. Motywy ikonograficzne malowideł przedkonstantyńskich w chrześcijańskich katakumbach Rzymu, Lublin 1990.

Zajęcki M., Cmentarz w mieście feudalnym, czyli o sacrum w obliczu zasady racjonalności, „Gryfiński Kwartalnik Historyczny” (2005) 1 (9), s. 21.

Visscher F., Le droit des tombeaux romains, Milano 1963. 